\title{
Living with a Scent of Danger
}

\author{
BY \\ VITAUT KIPEL* \\ Stankievich, Joanne Ivy. \\ Living with a Scent of Danger: Adventures at the Fall of Communism, \\ Outskirts Press: Princeton, New Jersey, 2013. 244 pp. \\ $\$ 16.95$ \\ ISBN: 9781432775865.
}

This compelling narrative of 'European adventures' chronicles the remarkable career of two very different, very gifted professionals, Joanne Ivy Stankievich, the daughter of homesteaders who settled and raised dairy cattle on a farm in the state of Washington, and Walter Stankievich, an historian, journalist, and Belarusian activist.

A memoir set during the last decades of the Soviet regime, it illuminates the challenges of spending time in a totalitarian country, which was, at the same time, the childhood homeland of the author's husband.

'Most of my information on Eastern Europe came from the news and spy stories', opens her memoir. What then evolves is, in many ways, a TV-worthy spy story itself, told by a versatile wife, mother, and intellectual partner.

The catalyst for the plot is a page taken from a familiar American scenario. Walter arrived in the United States under a program instituted during President Harry S. Truman's term of office, permitting a number of persons of East European background to immigrate to America. Having completed his education here, Walter was employed by a large company as an engineer. Suddenly a dramatic shift in the family's fortunes occurred. The firm did not obtain a government contract - and at age 55 - the family breadwinner was unemployed and faced with a 'What next?' moment.

Fortuitously, Radio Liberty/Radio Free Europe was, just at that time, recruiting for an important post in Europe. Walter's family background (Belarusian and Czech), professional experience linguistic skills, and long-term observation of the East European scene met the requirements of the position ideally. The job was his. This meant a major relocation, first to Munich and then to Prague.

\footnotetext{
* Dr Vytaut Kipel is President of Belarusian Institute of Arts and Sciences, New York City.
} 
On one level, this is the Bildungsroman of an exceptional marriage. The author grows in her appreciation of her husband's talents, integrity, and myriad skill sets. She loves him in an unqualified way. The people with whom he has professional association admire and respect him.

A modest man who does not trumpet his accomplishments, Walter Stankievich emerges here as a figure of influence and importance in many venues and circumstances in these pages. His ability soon elevated him to the position of Director of the Belarusian Service of Radio Liberty.

The exigencies of travel in the Soviet Union provide constant surprises, risks, and challenges. The author's profound faith is the rudder that surmounts anxiety and overcomes the pitfalls and dangers of a 'marked' foreigner (whose employment was chronicling the policies and politics of the Soviet regime).

When the Soviet regime fell, the Stankieviches decided to visit the newly independent Republic of Belarus. They met hundreds of ordinary citizens and members of the leadership cadre, exploring views, attitudes, and aspirations in the dramatic transition period of the early 1990s.

The kaleidoscope of their adventures is too rich to encapsulate. The reader is assured of a reading experience that is moving, arresting, and edifying. 